\title{
The CO2 level as a factor stimulating angiogenesis Phenomena of tissue regeneration and destruction
}

\section{Maciej Pawlikowski}

AGH - Univ. of Science and Technology, Cracow, Poland.

*Corresponding Author: Maciej Pawlikowski. AGH - Univ. of Science and Technology, Cracow, Poland.

Received date: October 30, 2020; Accepted date: November 02, 2020; Published date: November 17,2020

Citation: Pawlikowski M. (2020) The $\mathrm{CO}_{2}$ level as a factor stimulating angiogenesis Phenomena of tissue regeneration and destruction J, Biotechnology and Bioprocessing 1(2); DOI:10.31579/2766-2314/008

Copyright: (C) 2020, Maciej Pawlikowski, This is an open access article distributed under the Creative Commons Attribution License, which permits unrestricted use, distribution, and reproduction in any medium, provided the original work is properly cited.

\begin{abstract}
The regeneration of vessels and their development occur in places of their destruction. This phenomenon suggests that the destruction process itself stimulates vascular development and entails tissue healing and self-repair. Understanding the phenomena of self-repair is extremely important in the process of restoring tissues and organs to the proper functioning of individual organs and the entire body. Therefore, the recognition of angiogenesis processes seems to be the key in the treatment of many diseases.
\end{abstract}

Keywords: CO2 level; angiogenesis; tissue regeneration

Many years of research on blood vessels, their development and mineralization $[15,17,18,19,24,25,26,27,28,29,30,31,33]$, bone mineralization, demineralization and the process of bone healing $[12,13$, $32]$, as well as the phenomena of tumor mineralization [32, 16, 20, 21, 25, 27], have all provided a lot of observations on angiogenesis. The presented publication is a summary of many years of early research.

Views on the role of endothelium in angiogenesis are widely published [1, 2, 7, and 10]. Various substances have been proposed as a factor in the development of arteries, including vitamin D3. An important role in the development of angiogenesis is also attributed to perisytes, i.e. unorganized stem cells present in the vicinity of blood vessels [4]. The literature in many publications also reports on the formation of new vessels in neoplastic tissues [14. 32, 34, 36, 39]. The literature also provides examples of phenomena that inhibit the development of angiogenesis [3], often based on their computer modeling [5, 11].

Literature information and the results of own research suggest a similar cause of angiogenesis in various cases of vascular formation. This view will be presented below.

\section{Vascular development in the areas of their blockage \\ Collateral circulation}

In vessels blocked by substances crystallizing in them $[18,26]$, e.g. coronary vessels, the level of $\mathrm{CO}_{2}$ increases. This is the result of hypoxia, i.e. a change in the ratio between the oxygen level and the $\mathrm{CO}_{2}$ level at the point of blockage. Therefore, in the area of the artery blockage the oxygen level is low compared to the $\mathrm{CO}_{2}$ level, which increases as a result of the death of myocardial cells. Consequently, this phenomenon leads to the formation of easily dissociating carbonic acid $\left(\mathrm{H}_{2} \mathrm{CO}_{3}\right)$, formed from the local $\mathrm{CO}_{2}$ and water present in the tissues. As a result of this, the $\mathrm{pH}$ of the environment drops below 7.0. The angiogenesis itself, developing at the site of arterial blockage, can lead to the formation of collateral circulation (Photo 1).

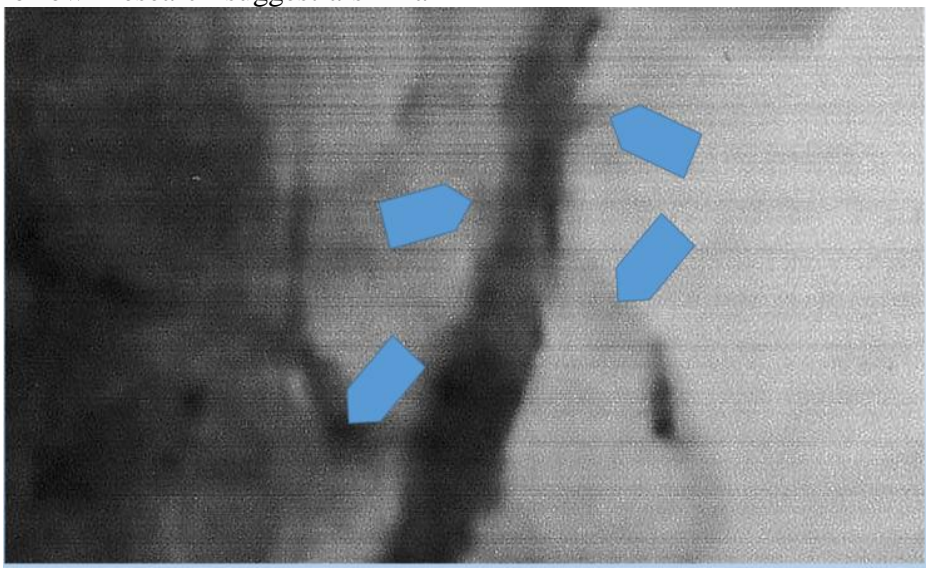

Photo 1. Development of secondary vessels (arrows) near a blocked coronary artery. Magnification 150x. 
In the case of neoplastic tumors, the newly formed concentrations of cells form numerous blood vessels that develop from both primary and secondary vessels (Photo 2). The rate at which these blood vessels form is often slower than the rate at which new cells are formed. That results in an increase in non-discharged $\mathrm{CO}_{2}$ causing local acidification of the environment.

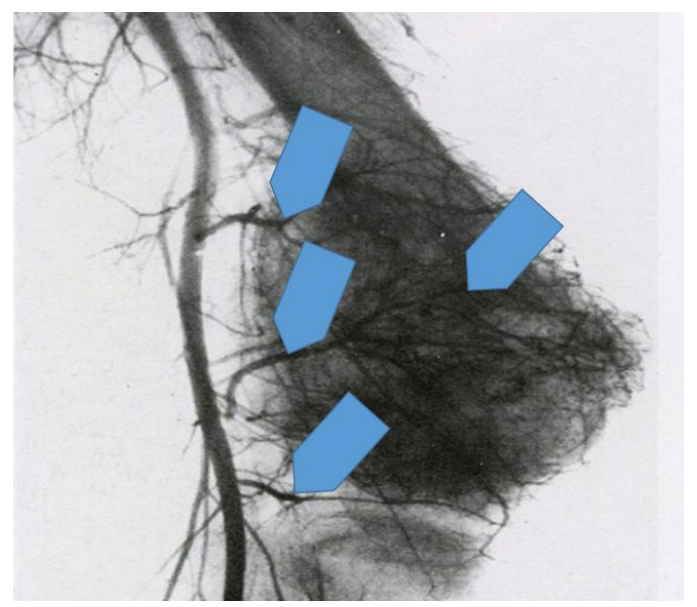

Photo 2. Numerous secondary blood vessels in the Liczne, wtórne naczynia krwionośne in a tumor of the lower base of thigh [32].

The phenomena described in this publication and their interpretation are based on studies of damaged arterial walls. It was noted that a damaged (for various reasons) artery wall may heal itself. The endothelial surface, which proliferates as a result of angiogenesis, forms particular structures that in further evolution lead to the formation of a new artery (Photo 3).

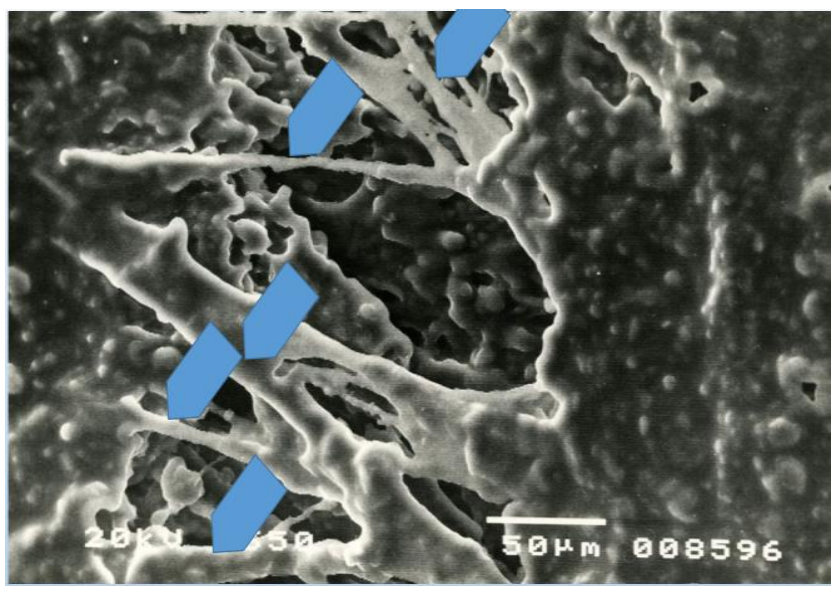

Photo 3. Endothelial growth phase at the site of damaged artery wall. Arrows show endothelial proliferation of the damaged artery. Scanning microscope, magnification according to scale.

\section{The phenomenon in the cell membrane of intima}

Endothelium is the site of many biochemical phenomena. One of the most important is the synthesis of prostacyclins, prostaglandins and thromboxanes, which are secreted into the blood and regulate its properties, including coagulability and the ability to aggregate. Research shows that individual elements of the cell membrane of intima have different functions (Figure 1). 


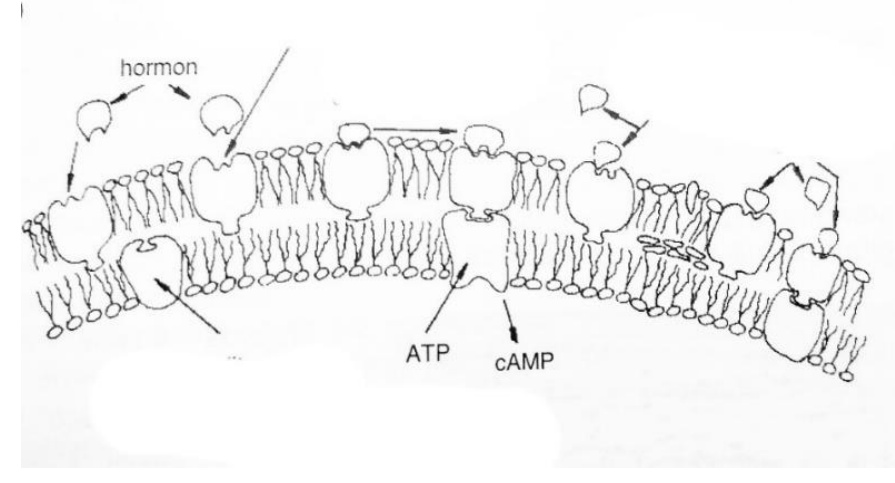

Figure 1. A general structure of a fragment of the intima cell membrane [38]

\section{Angiogenesis in a blocked artery (e.g. coronary vessel)}

Concentrations of cholesterol crystallizing in and on the artery wall can inhibit blood flow. This causes local increase in $\mathrm{CO}_{2}$ content in relation to the content of oxygen, which is not supplied by the blocked artery. The phenomenon causes local $\mathrm{CO}_{2}$ to react with water, leading to the formation of carbonic acid $\left(\mathrm{H}_{2} \mathrm{CO}_{3}\right)$. It dissociates easily and breaks down into free protons $\left(\mathrm{H}^{+}\right)$and $\mathrm{CO}_{3}{ }^{2-}$ carbonate groups. The above phenomena lead to a decrease in the local $\mathrm{pH}$ and development of acidic environment that is aggressive towards the artery, where the flowing blood has a $\mathrm{pH}$ of 7.2-7.3. The result is that the acidic environment damages the endothelium of the artery.

The place of damage (destruction) of the artery endothelium is the site where interatomic bonds of its biological structures are broken. Due to broken bonds in the area of destruction an electric field appears, i.e. a place where free protons, carbonate groups etc. can be attached. Thus, the site of endothelial damage is the center in which the construction of new endothelium and consequently new vessel takes place (Figure 2).

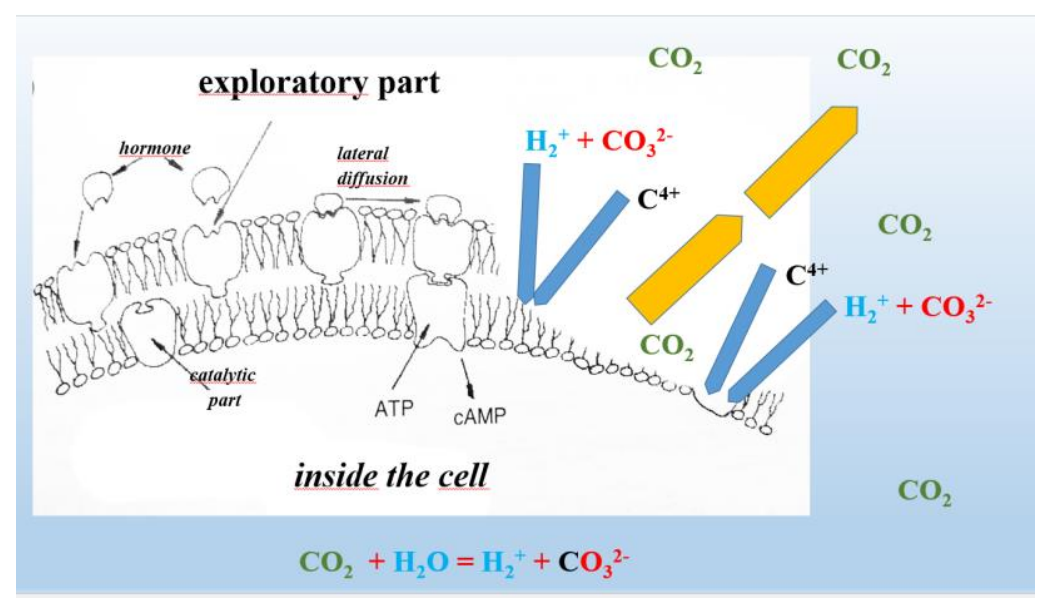

Figure 2. Generation of angiogenesis (collateral circulation) at the site of damage to the blocked artery (description in the text).

Protons and carbon from the $\mathrm{CO}_{3}{ }^{2-}$ groups build new biological structures at the site of damage to the endothelial cell membrane (blue arrows). The newly formed vessel (artery) proliferates in the direction shown by the yellow arrows.

\section{Angiogenesis in cancerous tumors}

In the case of angiogenesis in cancerous tumors, the phenomenon is similar. However, the cause of the local increase in the level of $\mathrm{CO}_{2}$ is different than in the case of artery blockage. Here, the reason is the huge number of cells that multiply, each of them producing carbon dioxide in its life processes. The locally existing blood vessels are not able to evacuate the excess, which results in an increase in its quantity. The next stages of the phenomenon of angiogenesis generation and development proceed as described above, in the case of arterial blockage (Figure 3). 


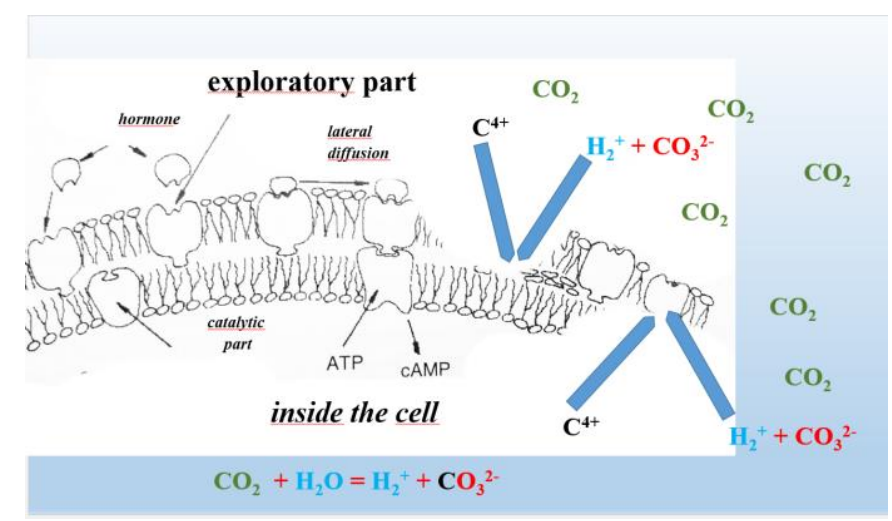

Figure 3. Development of angiogenesis in an oncological tumor (description in the text).

Damaged endothelium proliferates using "local material" in the form of protons and carbon to rebuild and initiate a new vessel.

\section{Angiogenesis in a broken bone}

While the cause of angiogenesis in bone fracture healing is different, it actually comes down to the phenomena described above for blocked arteries and tumors. In this case, there is also a local increase in the $\mathrm{CO}_{2}$ level. It is caused by the rupture of blood vessels during the fracture. The environment at the fracture site (especially in the fracture gap) contains an increased amount of $\mathrm{CO}_{2}$. This is caused by the inability to drain it through damaged vessels. Increased amount of carbon dioxide leads to the formation of dissociating carbonic acid and the phenomenon continues as described for blocked arteries and tumors.

Due to the fracture, the arteries are damaged mainly in the form of ruptures. Thus, the damage occurs at the tips of the broken arteries, and that is where angiogenesis begins. As a result, the proliferation of newly formed vessels in the fracture zone takes place from the bone fracture to the bone fracture (Figure 4). The process of angiogenesis itself is similar to that in tumors and blocked vessels.

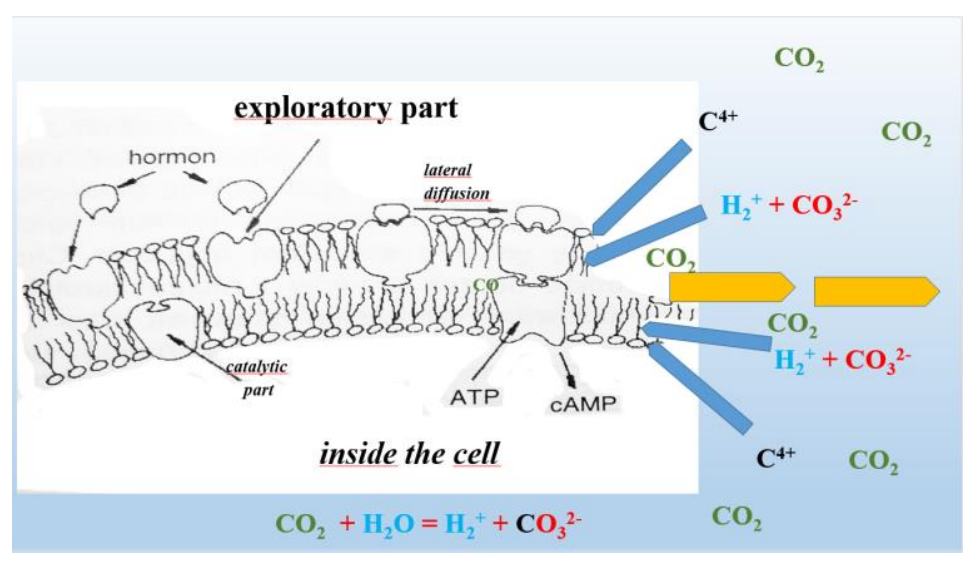

Figure 4. Generation of angiogenesis in bone fracture (explanation in the text).

The phenomenon of new artery generation in the artery endothelium at the site of vessel rupture. Material for the newly developing artery is collected from the local environment (blue arrows). The direction of growth of the newly formed vessel runs roughly from one bone fragment to the other (yellow arrows).

\section{Conclusion:}

1. Angiogenesis develops in areas with arterial damage, i.e. places where excess $\mathrm{CO}_{2}$ cannot be discharged through damaged vessels (veins). Another area with excess $\mathrm{CO}_{2}$ are cancer tissues, where the levels of $\mathrm{CO}_{2}$ raise due to fast increase in number (proliferation) of cells.

2. Locally high level of $\mathrm{CO}_{2}$ leads to the formation of aggressive carbonic acid $\mathrm{H}_{2} \mathrm{CO}_{3}$, which can destroy the cell membrane of endothelial cells.

3. Damaged areas are places where the atomic structures of the organic components that make up the intima cell membrane have a broken interatomic bond.
4. These damaged areas in the structure of endothelial cell membranes are endowed with electric charges. This is where the formation of new vessels (angiogenesis) starts.

5. The "building blocks" for the development of new vessels are hydrogen and calcium from easily-dissociated $\mathrm{H}_{2} \mathrm{CO}_{3}$ that is created from the excess $\mathrm{CO}_{2}$.

6. Depending on the cause of the arterial damage, angiogenesis develops along the axis of the vessel (in fractures) or in multiple directions (collateral circulation of blocked arteries or neoplastic tissue).

7. Considering the above observations, it is possible to accelerate or inhibit the development of angiogenesis by regulating the local level of $\mathrm{CO}_{2}$.

8. If it is necessary to accelerate angiogenesis, the $\mathrm{CO}_{2}$ level in the area of the blocked artery or bone fracture should be locally increased. 
9. If it is necessary to stop angiogenesis, the locally produced carbonic acid needs to be neutralized. This is important in blocking tumor angiogenesis and thus fighting the disease.

10. Separate studies are required to fully identify methods of accelerating and blocking angiogenesis.

\section{References}

1. Bai, J., Khajavi, M., Sui, L. et al. (2020) Angiogenic responses in a 3D micro-engineered environment of primary endothelial cells and pericytes. Angiogenesis.

2. Bajaj P., Schweller R.M., Khademhosseini A., West J.L., Bashir R., (2014) 3D biofabrication strategies for tissue engineering and regenerative medicine. Annu. Rev. Biomed. Eng. 16:247-276.

3. Benedito R., Roca C., Sorensen I., Adams S., Gossler A., Fruttiger M., Adams R.H., (2009) The notch ligands D114 and Jagged1 have opposing effects on angiogenesis. Cell 137 (6):1124-1135.

4. Bergers G., Song S., (2005) The role of pericytes in bloodvessel formation and maintenance. Neuro Oncol. 7 (4):452464.

5. Carpentier, G., Berndt, S., Ferratge S., et al. (2020) Angiogenesis Analyzer for ImageJ - A comparative morphometric analysis of "Endothelial Tube Formation Assay" and "Fibrin Bead Assay". Sci. Rep. 10: 11568.

6. Eichholz A., Merchant S., Gaya A., (2010) Anti-angiogenesis therapies: their potential in cancer management. Onco. Targets Therapy 3: 69-82.

7. Gerhardt H, Golding M, Fruttiger M, Ruhrberg C, Lundkvist A, et al (2003) VEGF guides angiogenic sprouting utilizing endothelial tip cell filopodia. J Cell Biol 161(6): 1163-1177.

8. Harper J, Moses M. A., (2006) Molecular regulation of tumor angiogenesis: mechanisms and therapeutic implications. EXS 96: 223-268.

9. Kurzyk A., 2014 Angiogenesis - possibilities, problems and perspectives.

10. Lobov I. Mikhailova N., (2018) The role of Dll4/Notch signaling in normal and pathological ocular angiogenesis: D114 controls blood vessel sprouting and vessel remodeling in normal and pathological conditions. J. Ophthalmol 356: 52-92.

11. Motherwell J., Murfee W.L., (2018) Modelling microvascular pathology. Nat. Biomed. Eng. 2 (6):349-350.

12. Niedźwiedzki T., Pawlikowski M., (1990) Mineralogical phenomena observed at healing part of broken bones. Chirurgia Narz. Ruchu i Ortop. Pol. T. LV, 277-281.

13. Niedźwiedzki T., Dąbrowski Z., Miszta H., Pawlikowski M., (1993) Bone healing after bone marrow stromal cell transplantation to the bone defect. Biomaterials, v. 14, no.2: 115-121.

14. Palikuqi, B., Nguyen, D.T., Li, G. et al. (2020) Adaptable haemodynamic endothelial cells for organogenesis and tumorigenesis. Nature 585: 426-432.

15. Pawlikowski M., (1987) Mineralization of human living organism. Prace Mineral. 79, 121 p.

16. Pawlikowski M., (1991d) Mineralization of cancer tumors In: A. Szymański Biomineralogia i biomateriały. PWN Warszawa: 97-102.

17. Pawlikowski M., (1993) Crystals of human organism. Secesja. (Atlas), $132 \mathrm{p}$.

18. Pawlikowski M., (1999) Preliminary results of dissolution of substances mineralizing human arteries. Arch. Mineralog. T.LII: $195-210$.
19. Pawlikowski M., (2003) Minerals in human blood vessels and their dissolution in vitro, In: Skinner H.C.W., Berger A. W., Geology and health. N.Y. - Oxford. Oxford Univ. Press: 155158.

20. Pawlikowski M., (2011) Biomineralization of cancer tissues. $20^{\text {th }}$ Int. Symp. Molecular and Physiological Aspects of Regulatory Processes of the Organism. Cracow. Ed. H. Lach. Wyd. Abaton. Kraków: 190-191.

21. Pawlikowski M., (2013) Mineralization of lung cancer tumors. Auxiliary sciences in archaeology, preservation of relicts and environmental engineering. CD -no 15, Ed. M Pawlikowski

22. Pawlikowski M. (2014) Osteoporosis as a source of tissue mineralization. Research on osteoporosis therapy and dissolution of arterial mineralization. Jour. Life Science Vol. 8, No. 7: 610-625.

23. Pawlikowski M., (2016) Biomineralogy of osteoporosis. Academia Journal of Biotechnology 4(4): 138-144.

24. Pawlikowski M (2018) Problems of Biomineralization Dissolution in Human Arteries. Adv. Card. Res. 1(4): 68-74.

25. Pawlikowski M., (2019) "Blockers for Crystallization Centers". EC Emergency Medicine and Critical Care 3.12: 1-5.

26. Pawlikowski M., (2020a) Artery biomineralization and its dissolution. ES J Cardiolog. 1(1): 1006.

27. Pawlikowski M., (2020b) Tissue Biomineralization as a Mechanism Leading to Cancer Development. J Carcinog Mutagen. 11:347.

28. Pawlikowski M., Pfitzner R., (1995a) Mineralogical methods useful for examination of human tissues. Przegl. Lekarski 52, 4: 119-123.

29. Pawlikowski M., Pfitzner R., (1995b). Mineralogical methods useful for examination of human tissues. Mineralization of heart structures. Przegl. Lekarski 52, 4: 24-27.

30. Pawlikowski M., Pfitzner K., Skinner C. (1995c) Cholesterolmineral concentrations of the aneurysmatic wall. Acta Angiologica. Supl. 1: 15.

31. Pawlikowski M., Pfitzner R., (1999) Mineralization of heart and big blood vessels). Wyd. IGSMiE PAN Kraków, 142 p.

32. Pawlikowski M., Niedźwiedzki T., (2002) Mineralogy of bones, Wyd. PAN Oddział w Krakowie, 128p.

33. Pawlikowski M., Ryskala Z., (1991). Mineralogical - chemical characteristic of phosphate mineralization of human arteries. Roczniki Nauk. - Dyd. WSP w Krakowie Prace Fizjologiczne: 81-104.

34. Servan-Schreiber D., (2012) Antyrak, Albatros. Warszawa. 304 p.

35. Shahneh F.Z., Baradaran B., Zamani F., Aghebati-Maleki L., (2013) Tumor angiogenesis and anti-angiogenic therapies. Hum Antibodies 22: 15-19.

36. Thurston G., Kitajewski J., (2008) VEGF and Delta-Notch: interacting signalling pathways in tumour angiogenesis. $\mathrm{Br}$. J. Cancer 99 (8):1204-1209.

37. Wietecha M.S., Cerny W.L., Di Pietro L.A., (2013) Mechanisms of vessel regression: toward an understanding of the resolution of angiogenesis. Curr. Top Microbiol Immunol 367: 3-32

38. Wetulani J., (1983) Biochemical methods of investigation of brain receptors). In: Nowe metody w badaniach mózgu. Seria. Najnowsze osiągnięcia nauki. Ed. Ossolineum.

39. Unterleuthner D., Neuhold P., Schwarz K., Janker L., Neuditschko B., et al (2020) Cancer-associated fibroblastderived WNT2 increases tumor angiogenesis in colon cancer. Angiogenesis 23:159-177. 